\title{
EXPERIMENTAL INVESTIGATION OF ENERGY CHARACTERISTICS OF EVACUATED TUBE HEAT-PIPE SOLAR COLLECTOR SYSTEM
}

\author{
Antanas KAVOLYNAS. Institute of Energy and Biotechnology Engineering, Aleksandras Stulginskis University, Studentu g. 15, \\ Akademija, LT-53362 Kaunas raj., Lithuania, antanas.kavolynas@asu.lt (corresponding author) \\ Rolandas DREJERIS, Institute of Business and Rural Development Management, Aleksandras Stulginskis University, Universiteto \\ g. 10, Akademija, LT-53361 Kaunas raj., Lithuania, rdrejeris@ gmail.com
}

Evacuated tube heat-pipe solar collector system with closed heat pipe has been experimentally investigated. Experiments have been fulfilled using the solar imitator whose energy irradiance on the surface of the solar collector at the constant ambient conditions is $800 \mathrm{~W} / \mathrm{m}^{2}$. Energy characteristics of the solar collector system with different flow-rates of the heat-transfer agent have been investigated using various flow-rate speeds of the heat-transfer agent. It has been stated that the increase of the flowrate of the heat-transfer agent in the system from 0.01 to $0.12 \mathrm{~kg} / \mathrm{s}$ would minimize the average collector efficiency from 0.81 to 0.55 . When the reduced flow-rate of the heat-transfer agent has been used in the system, the higher temperature of the hot water is reached in the storage tank and at the same time the temperature of the heat-transfer agent in the system is increased. Thus, more energy has been lost in the pipeline and hot water storage tank, but less energy is used for the circulation of the heat-transfer agent energy. Increasing the agent flow-rate speed in the system has reduced the heat losses in the pipeline, but more energy is used for the energy circulation of the heat-transfer agent. Therefore, the medium efficiency of the solar collector system has changed insignificantly $(0.47 \pm 0.01)$.

Keywords: solar collector, fluid flow rate, system, energy, efficiency.

\section{INTRODUCTION}

The increasing energy consumption reflects the growth of the modern needs of the developing society. But the increased use of the energy resources has the negative effect on the environment and climate change. Thus, the use of the solar energy for the heating needs is one of the attractive modern and environmentally-friendly possibilities to apply these technologies.

The solar energy is used for the heating of water and premise in residential houses. The solar collectors of various structures are used to convert the solar energy into the thermal energy. In $20142.9 \mathrm{mln}$. $\mathrm{m}^{2}$ of the glazed solar collector area had been newly installed in the EU member states. And according to the data of 2015 (ESTIF, 2015) the area of the glazed solar collectors had already reached $45.4 \mathrm{mln} . \mathrm{m}^{2}$. In the solar collector systems have been installed $83.8 \%$ of the flat plate and $10.5 \%$ of the evacuated tube solar collectors from all the installed collector number. Approximately $84 \%$ of all the installed solar collectors are used in small collector systems of residential houses (Mauthner et al., 2015).

In 2012 about $600 \mathrm{~m}^{2}$ flat plate solar collectors and $1200 \mathrm{~m}^{2}$ evacuated tube solar collectors had been installed in Lithuania. And in 2013 about $800 \mathrm{~m}^{2}$ flat plate solar collectors and $1400 \mathrm{~m}^{2}$ evacuated tube solar collectors had been additionally installed. At the end of 2014 the area of the glazed solar collectors was $10400 \mathrm{~m}^{2}$ in Lithuania (ESTIF, 2015). About 1640 compulsory circulation of the heat-transfer agent type solar collector systems have been installed in the private houses and they are mostly used for the water heating. The solar collector systems used in Lithuania have generated about $4 \mathrm{GWh}$ of heat energy and minimized the fuel consumption by $380 \mathrm{t}$ of oil equivalent and reduced the environment pollution with $\mathrm{CO}_{2}$ gas by $1229 \mathrm{t}$ per year (Mauthner et al., 2015).

The flat plate and various types of evacuated tube solar collectors are used in different solar collector systems installed in Lithuania. The evacuated tube solar collectors are famous for their good optical characteristics (Ma et al., 2013) and insignificant heat losses (Badar et al., 2011). For the heat transfer in the evacuated tube solar collectors are mostly used closed heat pipes the effectiveness of which depends on the heat pipe structure (Sivaraman and Krishna

Copyright (C) 2015 The Authors. Published by Aleksandras Stulginskis University. This is an open-access article distributed under the terms of the Creative Commons Attribution License (CC-BY 4.0), which permits unrestricted use, distribution, and reproduction in any medium, provided the original author and source are credited. 
Mohan, 2005), the composition of the used agent (Hussein et al., 2006) and the flow-rate of the heat-transfer agent of the system (Sivakumar et al., 2011).

The efficiency of the evacuated tube solar collectors can be $0.78-0.88$ (Ayompe et al., 2011) depending on the collector structure, but the average efficiency is not very high $0.58-0.74$ (Islam et al., 2013). Meanwhile, the effectiveness of the small solar collector systems used for water heating depends on the energy indices of the equipment used in the system (Wang et al., 2015). The effectiveness of the simple structure solar collector systems with compulsory circulation of the heat-transfer agent is from 0.43 to 0.60 (Gang et al., 2012; Ayompe and Duffy, 2013). It has been stated that operating the flow-rate speed of the heat-transfer agent of the solar collector system, the system effectiveness can be increased by using the less energy for the agent circulation (Huang et al., 2012). The small solar collector systems with evacuated tube solar collectors have not been widely investigated. Therefore, it is expedient to investigate and evaluate the effectiveness of the typical system and to find the potential possibilities to increase the effectiveness.

The aim of the research is to define the energy features of the evacuated tube heat-pipe solar collector system using various flow-rates of the heat-transfer agent in the system.

\section{MATERIALS AND METHODS}

The solar collector system with the compulsory close-flow circulation of the heat-transfer agent has been experimentally investigated (Fig.1). The system consists of evacuated tube heat-pipe solar collector the parameters of which are $F_{R}(\tau \alpha)_{n}=0.79$ and $F_{R} U_{L}=2.51 \mathrm{~W} /\left(\mathrm{m}^{2} \mathrm{~K}\right)$. The surface of the transparent covering of the solar collector is $1.13 \mathrm{~m}^{2}$, and the surface of the absorbing coating is $0.97 \mathrm{~m}^{2}$.

The vertical cylindrical hot water storage tank (HWST) of 80 liters capacity with the comparative heat losses of $2.13 \mathrm{~W} / \mathrm{K}$ is installed in the solar collector system. The storage tank is covered by $50 \mathrm{~mm}$ thickness stone wool thermal insulation $(\lambda=0.036 \mathrm{~W} /(\mathrm{m} \mathrm{K}))$. The height and diameter ratio of the HWST is $\mathrm{H} / \mathrm{d}=2.22$, and the copper spiral-type heat exchanger with the surface area of $0.28 \mathrm{~m}^{2}$ is installed in the storage tank.

The solar collector system is connected with $15 \mathrm{~mm}$ diameter copper pipes covered with $25 \mathrm{~mm}$ density stone wool thermal insulation $(\lambda=0.036 \mathrm{~W} /(\mathrm{m} \mathrm{K}))$. The solar collector system is filled up with (5.0 1) of the heat-transfer agent circulated by the pump ,Solar PM 15-60“.

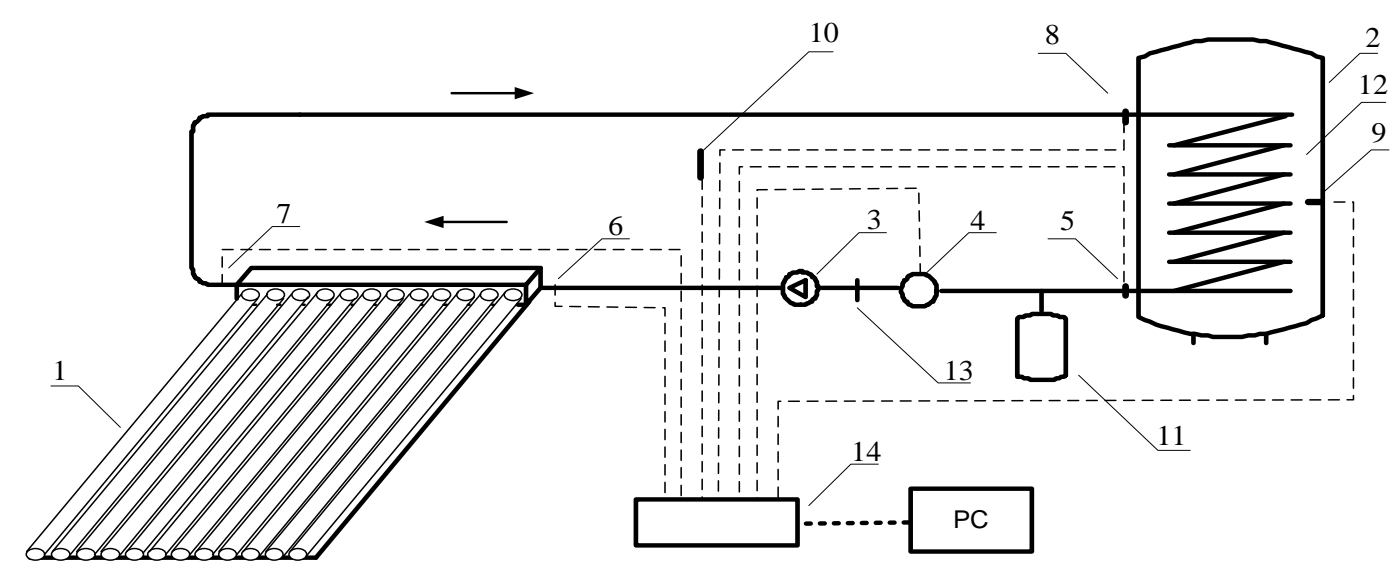

Figure 1. Evacuated tubes solar collector system stand: 1 - solar collector, 2 - hot water storage tank, 3 - circulation pump, 4 - yield meter, 5-10 - temperature sensors, 11 - expansion tank, 12 - heater coil, 13 - yield valve, 14 - measurement equipment.

The experiments are fulfilled using the solar imitator that has created the energy irradiance of $800 \pm 30 \mathrm{~W} / \mathrm{m}^{2}$ on the surface of the collector. The irradiance has been measured by the pyranometer CMP-3/6006, with the accuracy of $\pm 15 \mathrm{~W} / \mathrm{m}^{2}$. The collector has been air-entrained with the average air flow of $2 \mathrm{~m} / \mathrm{s}$ during the tests. The temperature has been measured with the sensors Pt-100 the ability of which to discern is $0.01{ }^{\circ} \mathrm{C}$. During the investigation the following temperatures have been measured: inlet $\left(t_{\mathrm{ic}}\right)$ and outlet $\left(t_{\mathrm{oc}}\right)$ temperatures of the heat-transfer agent of the collector, the inlet and outlet temperatures of the heat-transfer agent in the HWST heat exchanger, the water temperature $\left(t_{\mathrm{s}}\right)$ of the storage tank, and the ambient temperature $\left(t_{\mathrm{a}}=25.5 \pm 0.5^{\circ} \mathrm{C}\right)$. The flow-rate of the heat-transfer agent in the system has been measured by the meter FV A915 VTH15M/P. The data of the temperature and flow-rate sensors have been registered by the instrument AMR 5690-2.

The efficiency of the solar collector is determined by the following expression (Ayompe et al., 2011):

$$
\eta_{c}=\frac{m c_{f}\left(t_{o c}-t_{i c}\right)}{G A}
$$


where: $m$ - flow-rate of the heat-transfer agent, $\mathrm{kg} / \mathrm{s} ; c_{f}$ - specific heat of the heat-transfer agent, $\mathrm{J} /(\mathrm{kg} \mathrm{K}) ; t_{i c}, t_{o c}-$ inlet and outlet temperature of the heat-transfer agent of the solar collector, ${ }^{\circ} \mathrm{C}$; $G$ - energy irradiance of the collector surface, $\mathrm{W} / \mathrm{m}^{2} ; A$-transparent covering area of the solar collector, $\mathrm{m}^{2}$.

The amount of the hot water accumulated in the storage tank is determined according to the following expression (Ayompe et al., 2011):

$$
Q_{S T}=\frac{m_{s} c_{f}\left(t_{i s}-t_{e s}\right)}{3600000},
$$

where: $m_{s}$ - water mass in the hot water storage tank, $\mathrm{kg} ; c_{f}$-specific heat of water, $\mathrm{J} /(\mathrm{kg} \mathrm{K}) ; t_{i s}, t_{e s}-$ initial and end water temperature in the hot water storage tank, ${ }^{\circ} \mathrm{C}$.

The effectiveness of the solar collector system is determined by the following expression (Ayompe and Duffy, 2013):

$$
\eta_{s y s}=\frac{Q_{S T}}{Q_{S}}
$$

where $Q_{S}$ - energy quantity on the transparent covering of the solar collector, $\mathrm{kWh}$.

\section{RESULTS AND DISCUSSION}

Experimental investigation disclosed that the solar collector can reach high efficiency of $0.81 \mathrm{when} 0.01 \mathrm{~kg} / \mathrm{s}$ flow-rate of the heat-transfer agent has been used in the solar collector system. Thus, the average temperature difference in the solar collector is $16.47^{\circ} \mathrm{C}$, and the average instantaneous thermal power of the collector is $690 \mathrm{~W}$. Meanwhile, the temperature difference of the heat-transfer agent in the heat exchanger of the HWST is $14.57{ }^{\circ} \mathrm{C}$, and the instantaneous average power of the heat exchanger is $610 \mathrm{~W}$. During the tests that have been lasting for $8.33 \mathrm{~h}$, $6.66 \mathrm{kWh}$ of the energy has reached the surface of the solar collector, the solar collector has generated $5.74 \mathrm{kWh}$ of thermal energy, and the HWST of the system has accumulated $3.33 \mathrm{kWh}$ of the heat. During this investigation the average temperature of the heat-transfer agent in the system pipeline is $56.8^{\circ} \mathrm{C}$, thus the loss of the heat in the system pipeline is $0.66 \mathrm{kWh}$.

Table 1. Parameter values of the solar collector and the system at various flow-rate speeds of the heat-transfer agent

\begin{tabular}{|c|c|c|c|c|}
\hline $\begin{array}{c}\text { Flow-rate of the } \\
\text { heat-transfer agent } \\
\mathrm{m}, \mathrm{kg} / \mathrm{s}\end{array}$ & $\begin{array}{c}\text { Solar collector } \\
\text { efficiency, } \eta_{c}\end{array}$ & $\begin{array}{c}\text { Temperature difference } \\
\text { in the solar collector, } \\
{ }^{\circ} \mathrm{C}\end{array}$ & $\begin{array}{c}\text { Temperature difference in the } \\
\text { hot water storage tank of the } \\
\text { heat exchanger, }{ }^{\circ} \mathrm{C}\end{array}$ & $\begin{array}{c}\text { The energy used for the } \\
\text { circulation of the heat- } \\
\text { transfer agent, } \mathrm{kWh}\end{array}$ \\
\hline 0.01 & $0.81 \pm 0.04$ & $16.47 \pm 0.68$ & $14.57 \pm 0.66$ & 0.25 \\
\hline 0.02 & $0.73 \pm 0.04$ & $7.45 \pm 0.37$ & $6.75 \pm 0.35$ & 0.37 \\
\hline 0.04 & $0.66 \pm 0.03$ & $3.36 \pm 0.21$ & $3.13 \pm 0.20$ & 0.49 \\
\hline 0.06 & $0.61 \pm 0.03$ & $2.09 \pm 0.10$ & $1.98 \pm 0.10$ & 0.57 \\
\hline 0.08 & $0.58 \pm 0.03$ & $1.49 \pm 0.08$ & $1.44 \pm 0.07$ & 0.62 \\
\hline 0.10 & $0.56 \pm 0.03$ & $1.15 \pm 0.07$ & $1.12 \pm 0.06$ & 0.67 \\
\hline 0.12 & $0.55 \pm 0.03$ & $0.94 \pm 0.06$ & $0.90 \pm 0.05$ & 0.70 \\
\hline
\end{tabular}

The average instantaneous power of the solar collector is $526 \mathrm{~W}$ when the flow-rate of the heat-transfer agent of $0.06 \mathrm{~kg} / \mathrm{s}$ has been used in the solar collector system, therefore during the period of $8.33 \mathrm{~h}$ it can generate approximately $4.38 \mathrm{kWh}$ of heat. But when the greater flow-rate of the heat-transfer agent of $0.12 \mathrm{~kg} / \mathrm{s}$ is used in the system, the temperature difference in the solar collector decreases to $0.94{ }^{\circ} \mathrm{C}$, thus the collector instantaneous power and the quantity of the generated energy reduces to $3.92 \mathrm{kWh}$ during the same period.

The investigation has shown that the efficiency of the evacuated tube solar collector is less when the greater flow-rate speed of the het-transfer agent has been used in the system (Fig.3) and the generated energy amount minimizes. It has been determined that the energy amount (Fig.2) generated in the solar collector depends on the flowrate speed of the heat-transfer agent in the system and can be described by the progressive relationship $\left(R^{2}=0.99\right)$ :

$$
Q_{1}=2.825 m^{-0.155}, \quad R^{2}=0.99
$$

The difference of the energy generated in the solar collector and in the HWST of the heat exchanger reflects heat losses in the system pipeline. When the flow-rate speed in the system is $0.01 \mathrm{~kg} / \mathrm{s}$, the heat-transfer agent of higher temperature equal to $56.8^{\circ} \mathrm{C}$ circulates in the system, thus the greater difference between the heat-transfer agent and the ambient temperatures occurs the greater is the energy losses $(0.66 \mathrm{kWh})$ in the pipeline. But when the flow-rate speed in 
the system is increased to $0.6-0.12 \mathrm{~kg} / \mathrm{s}$, the average temperature of the heat-transfer agent in the system pipeline reduces from 54.7 to $53.1^{\circ} \mathrm{C}$, and less energy (0.22-0.07) is lost (Fig.2).

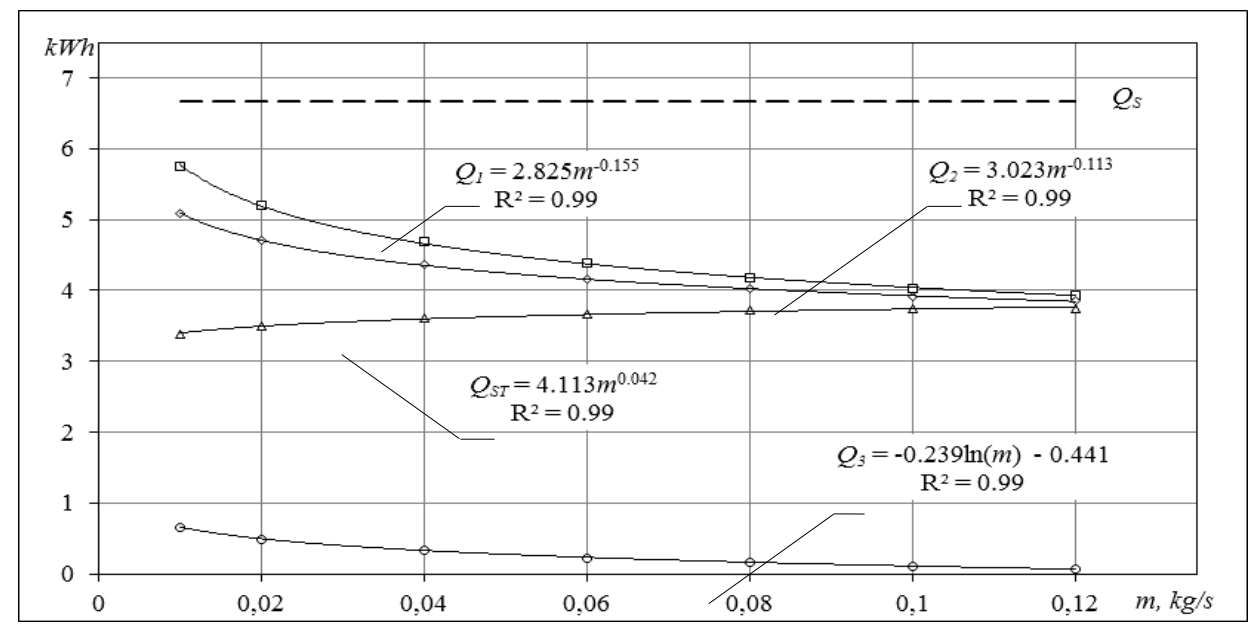

Figure 2. The energy flow-rates in the solar collector system at various flow-rates of the heat-transfer agent: $Q_{1}-$ energy generated in the solar collector; $Q_{2}$ - quantity of the energy transferred to the hot water tank of the heat exchanger; $Q_{3}$ - energy losses in the pipeline; $Q_{S T}$ - energy accumulated in the hot water storage tank; $Q_{S}$ - energy on the surface of the solar collector.

The experiments show that the heat-transfer agent of the lower temperature reaches the HWST of the heat exchanger due to the heat losses in the pipeline, thus the heat exchange produces less thermal power and the less temperature difference is reached in the heat exchanger. The thermal energy shift dynamics of the HWST heat exchanger is defined by the progressive relationship $\left(\mathrm{R}^{2}=0.99\right)$ when various flow-rate speeds are used:

$$
Q_{2}=3.302 m^{-0.113}, \quad R^{2}=0.99
$$

When $0.12 \mathrm{~kg} / \mathrm{s}$ flow-rate speed of the heat-transfer agent is used in the solar collector system, the HWST heat exchanger releases about $3.85 \mathrm{kWh}$ of the energy and the storage tank accumulates $3.74 \mathrm{kWh}$ of the heat. But when the slower $0.01 \mathrm{~kg} / \mathrm{s}$ flow-rate speed of the heat-transfer agent is used, the heat exchanger releases $5.09 \mathrm{kWh}$ of the energy, and the energy amount accumulated in the HWST reduces to $3.39 \mathrm{kWh}$. The shift dynamics of the energy amount accumulated in the HWST of the system is defined by the progressive relationship $\left(\mathrm{R}^{2}=0.99\right)$ when various flow-rate speeds are used:

$$
Q_{S T}=4.113 m^{0.042}, \quad R^{2}=0,99
$$

When the slower $0.01 \mathrm{~kg} / \mathrm{s}$ flow-rate speed of the heat-transfer agent is used in the solar collector system, the solar collector reaches the maximum efficiency of 0.84 more quickly and more heat energy is generated. Thus, the water temperature in the HWST rises more quickly, the temperature of the heat-transfer agent in the system increases, and the collector efficiency decreases to 0.77 . The above mentioned reasons determine the greater heat losses in the pipeline and HWST, thus more energy is lost and the amount of the accumulated energy reduces to $3.39 \mathrm{kWh}$.

The dependence of the efficiency of the evacuated tube solar collector used in the system on the flow-rate speed of the heat-transfer agent is rather accurately defined by the progressive relationship $\left(\mathrm{R}^{2}=0.99\right)$ :

$$
\eta_{c}=0.396 m^{-0.155}, \quad R^{2}=0.99
$$

When the $0.12 \mathrm{~kg} / \mathrm{s}$ flow-rate speed of the heat-transfer agent is used in the solar collector system, the average collector efficiency does not exceed 0.55 . The temperature difference of the heat-transfer agent reached in the collector minimizes to $0.94{ }^{\circ} \mathrm{C}$, and generates $3.92 \mathrm{kWh}$ of heat energy in the collector. When the collector generates less heat in the system, the average temperature of the heat-transfer agent minimizes to $53.1^{\circ} \mathrm{C}$ and less losses of $(0.07 \mathrm{kWh})$ are in the pipeline. Thus, the HWST of the system accumulates more $(3.74 \mathrm{kWh})$ of the heat energy. But the heat-transfer agent of the system with compulsory circulation uses more $(0.70 \mathrm{kWh})$ of electric energy. Therefore, evaluating energy flow-rates in the solar collector system, it has been determined that the average efficiency of the solar collector is 0.55 at the flow-rate speed of $0.12 \mathrm{~kg} / \mathrm{s}$, but the general effectiveness of the system does not exceed 0.47 . 


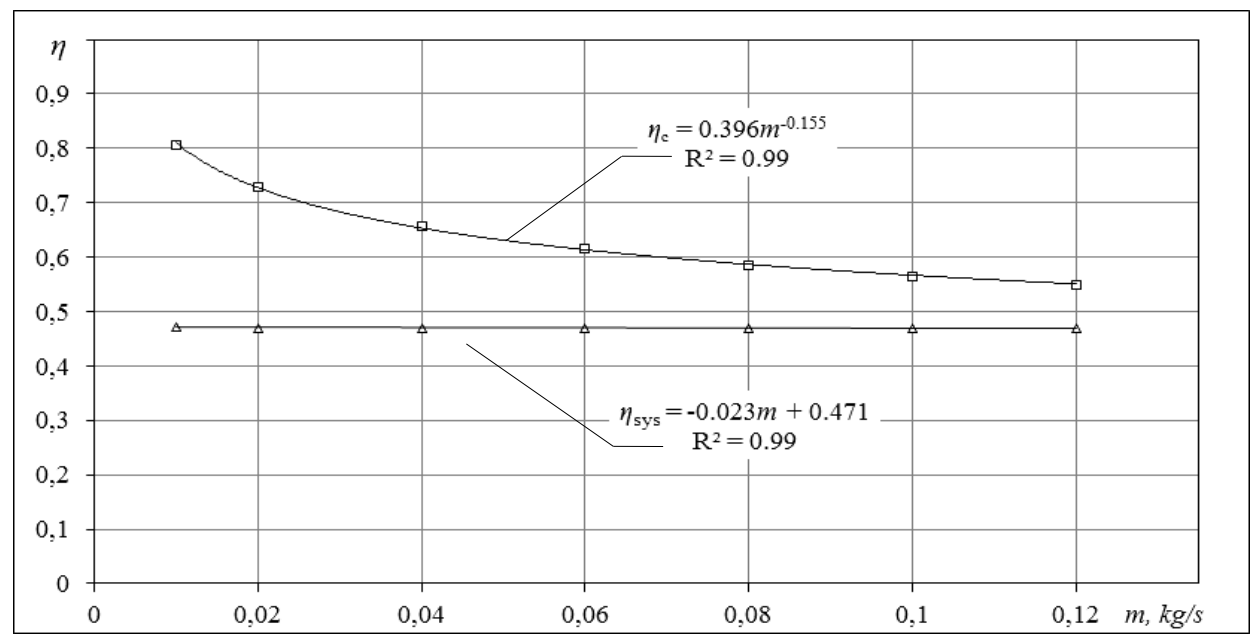

Figure 3. Dependence of the efficiency of the solar collector and the system on the flow-rate speed of the heat-transfer agent: $\eta_{\mathrm{c}}-$ efficiency of the evacuated tube solar collector; $\eta_{\mathrm{sys}}-$ effectiveness of the solar collector system.

When the flow-rate speed of the heat-transfer agent in the solar collector system is increased from $0.01 \mathrm{~kg} / \mathrm{s}$ to $0.12 \mathrm{~kg} / \mathrm{s}$, the efficiency of the solar collector minimizes from 0.81 to 0.55 and the temperature difference in the collector decreases from 16.47 to $0.94{ }^{\circ} \mathrm{C}$. Due to these circumstances the average temperature of the heat-transfer agent in the system minimizes, and the amount of the lost heat in the system pipeline reduces from 0.66 to $0.07 \mathrm{kWh}$. Increasing the flow-rate speed of the heat-transfer agent in the system, the higher water temperature in the HWST is slower achieved, thus less heat losses are experienced and more heat energy $(3.39-3.74 \mathrm{kWh})$ is accumulated. The investigation has been fulfilled using the compulsory circulation system where the circulation pump is used for the circulation of the heat-transfer agent. Therefore, using the slower $0.01 \mathrm{~kg} / \mathrm{s}$ flow-rate speed of the heat-transfer agent the $0.25 \mathrm{kWh}$ of the electric energy is used in the system, and using the greater $0.12 \mathrm{~kg} / \mathrm{s}$ flow-rate speed of the heat transfer agent the $0.7 \mathrm{kWh}$ of the electric energy is used. Thus, estimating the energy amounts converted and accumulated in the solar collector system and those used for circulation of the heat-transfer agent it has been defined that the system effectiveness $0.47 \pm 0.01$ changes insignificantly and does not depend on the flow-rate speed of the heat-transfer agent used in the system.

The investigation results show that using the slower $(0.01-0.02 \mathrm{~kg} / \mathrm{s})$ flow-rate speed of the heat-transfer agent in the solar collector system, the solar collector reaches high $(0.81-0.73)$ efficiency, and the less $(0.25-0.37 \mathrm{kWh})$ electric energy is used for the circulation of the heat-transfer agent. But more generated heat energy is lost in the pipeline and while accumulating the energy. Thus, when the energy generated in the solar collector is used directly refusing to accumulate the energy, the merits of the evacuated tube solar collector can be optimally used. But in the solar collector systems installed in the residential houses for the water heating it is difficult to refuse the energy accumulation. Therefore, trying to increase the effectiveness of the solar collector system all means should be analyzed enabling to minimize heat losses during the capacity charge of the HWST and the energy accumulation. For these purposes new hybrid heat accumulation technologies should be used and the means for the operating of the heat flow-rates should be also included in the solar collector systems.

\section{CONCLUSIONS}

It has been determined that the efficiency of the solar collector used in the solar collector system depends on the flow-rate speed of the heat-transfer agent of the system. When the flow-rate speed of the heat-transfer agent in the system is from 0.01 to $0.12 \mathrm{~kg} / \mathrm{s}$ the average efficiency of the solar collector minimizes from 0.81 to 0.55 .

When the flow-rate speed of the heat-transfer agent in the solar collector system is increased from 0.01 to $0.12 \mathrm{~kg} / \mathrm{s}$ the energy amount generated in the solar collector minimizes from 5.74 to $3.92 \mathrm{kWh}$ and the heat amount accumulated in the hot water storage tank of the system increases from 3.39 to $3.74 \mathrm{kWh}$. But the energy amount used for the circulation of the heat-transfer agent increases from 0.25 to $0.7 \mathrm{kWh}$ and the energy amount minimized due to the heat losses decreases from 0.66 to $0.07 \mathrm{kWh}$.

Estimating the energy flow-rates in the solar collector system it has been determined that the change of the flowrate speed of the heat-transfer agent in the system does not significantly influence the change of the overall system effectiveness $(0.47 \pm 0.01)$, and does not depend on the flow-rate speed of the heat-transfer agent. Thus, trying to achieve the higher effectiveness of the system the less speed of the heat-transfer agent should be used in the system and the heat losses in the hot water storage tank of the system should be minimized as well.

\section{REFERENCES}

1. Ayompe, L. M., Duffy, A., Mc Keever, M., Conlon, M., Mc Cormack, S. J. 2011. Comparative field performance study of flat plate and heat pipe evacuated tube collectors (ETCs) for domestic water heating systems in a temperate climate. Energy, Vol. 36, pp. 3370-3378. http://dx.doi.org/10.1016/j.energy.2011.03.034 
2. Ayompe, L. M., Duffy, A. 2013. Thermal performance analysis of a solar water heating system with heat pipe evacuated tube collector using data from a field trial. Solar Energy, Vol. 90, pp. 17-28. http://dx.doi.org/10.1016/j.solener.2013.01.001

3. Badar, A. W., Buchholz, R., Ziegler, F. 2011. Experimental and theoretical evaluation of the overall heat loss coefficient of vacuum tubes of a solar collector. Solar Energy, Vol. 85, pp. 1447-56. http://dx.doi.org/10.1016/j.solener.2011.04.001

4. ESTIF. 2015. Solar thermal markets in Europe: Trends and market statistics 2014. European Solar Thermal Industry Federation, Brussels, pp. 20.

5. Gang, P., Guiqiang, L., Xi, Z., Jie, J., Yuehong, S. 2012. Experimental study and exergetic analysis of a CPC-type solar water heater system using higher - temperature circulation in winter. Solar Energy, Vol. 86, pp. $1280-1286$. http://dx.doi.org/10.1016/j.solener.2012.01.019

6. Hussein, H. M. S., El-Ghetany, H. H., Nada, S. A. 2006. Performance of wickless heat pipe flat plate solar collectors having different pipe section geometries and filling ratios. Energy Conversion and Management, Vol. 47, Iss. 11-12, pp. 1539-1549. http://dx.doi.org/10.1016/j.enconman.2005.08.009

7. Huang, B. J., Ton, W. Z., Wu, C. C., Ko, H. W., Chang, H. S., Yen, R. H., Wang, J. C. 2012. Maximum-power-point tracking control of solar heating system. Solar Energy, Vol. 86, Iss. 11, pp. 3278-3287. http://dx.doi.org/10.1016/j.solener.2012.08.019

8. Islam, M. R., Sumathy, K., Khan, S. U. 2013. Solar water heating systems and their market trends. Renewable and Sustainable Energy Reviews, Vol. 17, pp. 1-25. http://dx.doi.org/10.1016/j.rser.2012.09.011

9. Mauthner, F., Weiss, W., Spörk-Dür, M. 2015. Solar Heat Worldwide. Markets and Contribution to the Energy Supply 2014. AEE INTEC.

10. Ma, F., Gao, W., Liu, T., Lin, W., Li, M. 2013. An experimental study on the impacts of key parameters of all-glass evacuated tubes on the thermal performances of all-glass evacuated tube solar water heaters. Journal of Renewable and Sustainable Energy, Vol. 5, pp. 1-14. http://dx.doi.org/10.1063/1.4803527

11. Sivakumar, K., Krishna Mohan, N., Sivaraman, B. 2011. Performance analysis of elliptical heat pipe solar collector. Indian Journal of Science and Technology, Vol. 4, ISs. 1, pp. 4-7.

12. Sivaraman, B., Krishna Mohan, N. 2005. Experimental investigation of heat pipe solar collector with different L/di ratio of heat pipe. Journal of Scientific \& Industrial Research, Vol. 64, pp. 698-701.

13. Wang, Z., Yang, W., Qiu, F., Zhang, X., Zhao, X. 2015. Solar water heating: From theory, application, marketing and research. Renewable and Sustainable Energy Reviews, Vol. 41, pp. 68-84. http://dx.doi.org/10.1016/j.rser.2014.08.026 